\title{
External stimuli help restore post-partum ovarian activity in Pelibuey sheep
}

\author{
S. Fraire-Cordero ${ }^{1,6}$, J. Salazar-Ortiz ${ }^{2}$, C. Cortez-Romero ${ }^{3}$, P. Pérez-Hernández ${ }^{4}$, C.A. Herrera- \\ Corredor $^{5}$ \& J. Gallegos-Sánchez ${ }^{6 \#}$ \\ ${ }^{1}$ Catedrática CONACyT, Campus Campeche, Colegio de Postgraduados, Campeche, 24450. México. \\ ${ }^{2}$ Campus Córdoba, Colegio de Postgraduados, Veracruz, 94946. México. \\ ${ }^{3}$ Campus San Luis Potosí, Colegio de Postgraduados, San Luis Potosí. 78622. México. \\ ${ }^{4}$ Campus Veracruz, Colegio de Postgraduados, Veracruz. 91690. México. \\ ${ }^{5}$ Facultad de Agronomía, Universidad Autónoma de San Luis Potosí, San Luis Potosí. 32. México. \\ ${ }^{6}$ Campus Montecillo, Colegio de Postgraduados, Estado de México, 56230. México.
}

(Received 28 July 2017; Accepted 27 November 2017; First published online 26 December 2017)

Copyright resides with the authors in terms of the Creative Commons Attribution 4.0 South African License.

See: http://creativecommons.org/licenses/by/4.0/za

Condition of use: The user may copy, distribute, transmit and adapt the work, but must recognize the authors and the South African Journal of Animal Science.

\begin{abstract}
Post-partum anestrus is a problem on farms, and its duration depends on the frequency and intensity of suckling which affects reproduction and production efficiency to become a determining economic factor. The aim of this study was to determine the post-partum reproductive response in ewe to a "male effect" with an ovulation induction protocol of five days using progesterone and the application of a metabolic restorative (MR; Metabolase (B). One hundred and twenty females were randomly assigned to one of four treatments: T1: Continuous suckling (CS; $n=29)$, T2: $C S+M R(n=29)$, T3: $C S$ + Male Effect (ME; $n=32)$, and T4: CS $+\mathrm{MR}+\mathrm{ME}$. The percentage of females in ovulation, weight changes among females and lambs, the onset of estrus, calving, fecundity, and prolificacy were also determined. The ovulation percentage was higher in CS $+\mathrm{ME}$ and $\mathrm{CS}+\mathrm{MR}+\mathrm{ME}(75.0$ and $73.3 \%)$ than in the other treatments. Weight changes in females and lambs were different among periods. The onset of estrus was similar for CS and CS + MR $(25.9 \pm 1.9$ and $25.7 \pm 0.7 \mathrm{~h}$, respectively). The calving percentage was higher for CS + MR (86.2\%) than other treatments. Male presence positively affected the postpartum cyclic ovarian re-establishment and the metabolic restorative could even improve the fertility of hair ewes in continuous suckling with similar hormone protocol.
\end{abstract}

Keywords: Male effect, metabolic stimulation, post-partum anestrus

\# Corresponding author: gallegos@colpos.mx

\section{Introduction}

In order to increase lamb production, it is necessary to reduce the time after delivery during which the frequency of gonadotropin-stimulating hormone $(\mathrm{GnRH})$ and luteinizing hormone $(\mathrm{LH})$ pulse secretion is inhibited, which prevent final follicle development and ovulation (Ungerfeld \& Sánchez-Dávila, 2012). There are various factors, such as race, male presence, suckling and nutrition, that affect this periodic cycling (Arroyo-Ledezma et al., 2000). In ewes, the reproductive function can be controlled with hormonal products, but their use is limited by high costs and demands for safe products (Martin \& Reza, 2016). One alternative is the use of socio-sexual cues exerted by the presence of rams (i.e., "male effect", Álvarez \& Zarco, 2001; Viana et al., 2016), which may be an efficient non-pharmacological method for the reduction of hormones and for restoring post-partum ovarian activity. In female sheep, a male presence stimulates the frequency of $\mathrm{GnRH} / \mathrm{LH}$ secretion, inducing ovulation and reducing the time interval from birth to first ovulation (MoralesTerán et al., 2011; Castillo-Maldonado et al., 2013).

After delivery, there is a metabolic imbalance in the ewe, which delays the reestablishment of ovarian activity and, depending on its intensity, may limit the growth of ovarian follicles. The mechanism through which substances participate in the hypothalamic and ovarian response to resume cyclic activity is partially known (Durmic \& Blache, 2012). Therefore, it is important to implement nutritional strategies at this stage to 
improve this metabolic imbalance. Our hypothesis was that a male presence accelerates the restart of cyclic ovarian activity and that the application of a metabolic restorative (Metabolase ${ }^{\circledR}$ ) and its combination with the male effect positively affect the reproductive variables of post-partum Pelibuey female sheep giving them an estrus induction protocol of five days. The objective was to evaluate the post-partum reproductive response of Pelibuey females to the male effect for 25 days, to an estrus induction protocol of five days with progesterone, and to the application of a metabolic restorative (Metabolase $\AA$ ) for two days before the withdrawal of progesterone.

\section{Materials and methods}

This study was carried out observing the standards for use and care of research animals at Colegio de Postgraduados, Campus Montecillo, Mexico, and according to Normas Oficiales Mexicana (Mexican Standards) NOM - 024 - ZOO - 1995 and NOM - 033 - ZOO - 1995 (SAGARPA, 2015).

The study was performed from December 2011 to June 2012 at the Reproduction Laboratory for Sheep and Goats (LaROCa), Colegio de Postgraduados, Campus Montecillo, State of Mexico, located at 2250 masl, $19^{\circ} 29^{\prime} \mathrm{N}$ and $98^{\circ} 53^{\prime} \mathrm{W}$, a region having a sub-humid temperate climate and summer rains (García, 2004). We used 120 multiparous Pelibuey ewes with their respective lambs and six sexually active adult rams, aged 4 years. The average weight of the females was $58.4( \pm 0.78) \mathrm{kg}$. The rams had good body condition and libido. Eight days after delivery, females and lambs were randomly assigned to one of the following treatments: T1: Continuous suckling $(C S ; n=29), T 2$ : $C S$ + Metabolic restorative (MR, Metabolase (B) Fatro SPA, Bologna, Italy, $n=29)$, T3: $C S+$ Male Effect $(M E, n=32)$, and T4: $C S+M R+M E(n=30)$, where $n$ indicates the number of individuals in the experiment (Figure 1).

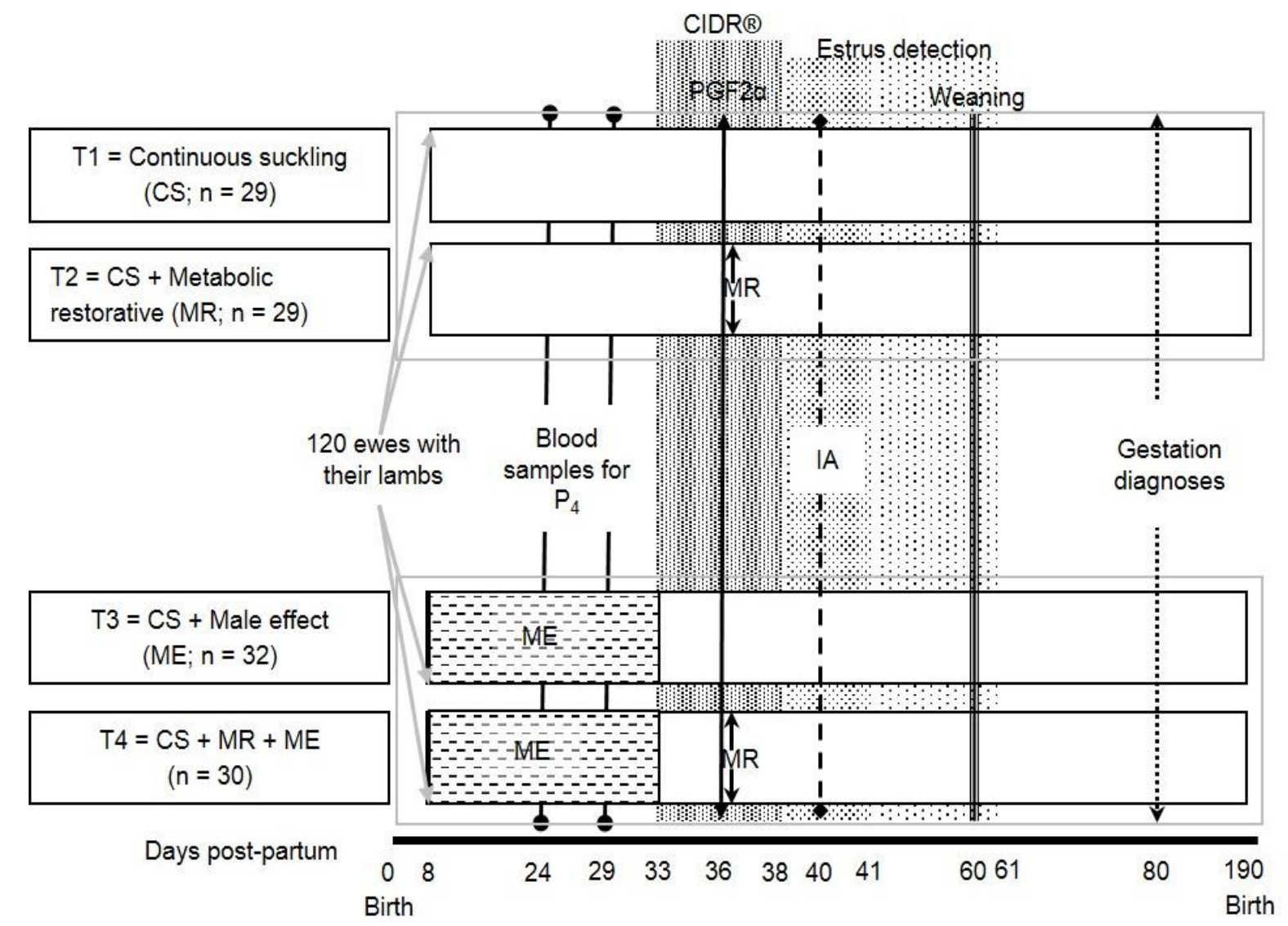

Figure 1 Research protocol

Females were isolated from the rams throughout gestation. At 50 days of gestation, a dose of selenium (MuSe ${ }^{\circledR}$; Schering-Plow, Mexico City, Mexico) per animal was injected subcutaneously ( $1 \mathrm{~mL}$ per $50 \mathrm{~kg}$ body weight). Subsequently, $2 \mathrm{~mL}$ of Toxo-Bac Pneumonia ${ }^{\circledR}$ vaccine (INIFAP, Yucatan, Mexico) was applied subcutaneously at $90 \mathrm{~d}$ of gestation. At birth, each lamb had its navel disinfected with $5 \%$ metallic iodine with alcohol, and $0.2 \mathrm{~mL}$ of MuSe ${ }^{\circledR}$ was injected subcutaneously. Female sheep and lambs were 
weighed every $9 \mathrm{~d}$ from birth to $81 \mathrm{~d}$ post-partum. Weaning of lambs was performed at $60 \mathrm{~d}$. In treatments three and four, two rams were introduced to the pen with an anti-copulatory apron for a period of $30 \mathrm{~min}^{-1}$ (at 08:00 and 16:00 h, respectively) each, from day eight until day 33 post-partum (Figure 1). Daily rotation of rams was performed to reduce their familiarity to the females.

Feed was provided twice a day in the same trough, offering females each time $1.5 \mathrm{~kg}^{-1}$ sheep ${ }^{-1}$ of a balanced feed $(70 \%$ oat hay and $30 \%$ commercial concentrate, Borrega Plus $\AA$, Unión Tepexpan, Texcoco, Estado de Mexico, Mexico, whit $15 \%$ crude protein and 2.9 Mcal of metabolizable energy kg ${ }^{-1}$ of DM). The rams were fed the same diet as females at the rate of $3.0 \mathrm{~kg} \mathrm{ram}^{-1}$ provided twice daily. Water and mineral salts (Vitasal Reproductor ${ }^{\circledR}$, SEPA, Texcoco, Estado de Mexico, Mexico) were offered ad libitum to all animals. The lambs were fed their mothers' milk, and from day 11 of age to weaning were offered a starter concentrate (Iniciador Dulce-20 ${ }^{\circledR}$, MNA, Nuevo León, Mexico, with $20 \%$ crude protein) ad libitum in exclusion feeders.

Blood samples were taken from all sheep on days 24 and 29 days post-partum (dpp; Figure 1) via jugular vein puncture and collected in Vacutainer tubes (Becton Dickinson Vacutainer Systems, Franklin Lakes, New Jersey, USA) without anticoagulant. Samples were centrifuged at $693 \times \mathrm{g}$ for $15 \mathrm{~min}$ (2500 rpm, Solbat $\circledast$ C-600 centrifuge, Solbat, Puebla, Mexico). The serum was then collected by decantation and stored at $-20{ }^{\circ} \mathrm{C}$ until analysis. To determine the concentration of progesterone $\left(\mathrm{P}_{4}\right)$, solid phase radioimmunoassay reagents (COAT-A-COUNT $\AA$, Siemens, California, USA) were used to analyze sensitivity at $0.02 \mathrm{ng} \mathrm{mL}^{-1}$ with an intra-assay coefficient of variation of $8.8 \%$. A female was considered to have restored ovarian activity when the $\mathrm{P}_{4}$ concentration was greater than $0.5 \mathrm{ng} \mathrm{mL}^{-1}$ in two consecutive samples, or more than $1 \mathrm{ng} \mathrm{mL}^{-1}$ of $\mathrm{P}_{4}$ in a single sample.

Estrus was induced in females at $33 \mathrm{dpp}$ with an intra-vaginal device (CIDR $\AA$, Pfizer, Hamilton, New Zealand) containing $0.3 \mathrm{~g}$ of $\mathrm{P}_{4}$ over five days. On the third day of the protocol, one $\mathrm{mL}$ of a PGF2 $\alpha$ analog (Celosil ${ }^{\circledR}$, Merck \& Dohme Corp., Kenilworth, New Jersey, USA) was applied intramuscularly to all females. In addition to treatments two and four, a dose of $200 \mathrm{~mL}$ of Metabolase $\AA$ (each $100 \mathrm{~mL}$ contains $613.3 \mathrm{mg} \mathrm{l-}$ carnitine hydrochloride, $20 \mathrm{mg}$ thioctic acid, $15 \mathrm{mg}$ pyridoxine hydrochloride, $3 \mathrm{mg}$ cyanocobalamin, 2,000 $\mathrm{mg} \mathrm{d}$-1-acetylmethionine, $240 \mathrm{mg} \mathrm{l-arginine,} 153.2 \mathrm{mg}$ l-ornithine hydrochloride, $120 \mathrm{mg}$ l-citrulline, $62.5 \mathrm{mg}$ I-lysine hydrochloride, $150 \mathrm{mg}$ glycine, $150 \mathrm{mg}$ aspartic acid, $150 \mathrm{mg}$ glutamic acid, $5,000 \mathrm{mg}$ fructose, and $8,000 \mathrm{mg}$ sorbitol) was given per animal, injecting $100 \mathrm{~mL}$ intravenously and $100 \mathrm{~mL}$ subcutaneously. On day 5 of the protocol, the $\mathrm{P}_{4}$ devices were removed, and estrus detection was started at $4 \mathrm{~h}$ intervals. A female was considered non-responsive if it did not show signs of estrus during a $70 \mathrm{~h}$ period. To detect estrus, six rams aged 4 years old, provided with an anti-copulatory apron were used. A female was considered to be in estrus when it remained motionless and allowed the ram to mount. Artificial insemination (Al) of the ewe was performed $12 \mathrm{~h}$ after estrus detection using $0.25 \mathrm{~mL}$ of cooled semen diluted to an average concentration of $230 \times 10^{6}$ spermatozoa per $\mathrm{mL}$. The semen used was collected from four rams, two from the Dorper breed and two from the Damara breed, aged two years old, and were represented in all treatments. Sample seminal quality was previously verified using macroscopic and microscopic tests of volume, color, density, mass motility, and individual motility. Forty days after Al, gestation diagnoses were performed with a portable ultrasound (USM CTS-900 ${ }^{\circledR}$, SIUI, China) equipped with a 3.5 - 7 Mhz abdominal transducer (Figure 1).

The response variables studied included the percentage of females that ovulated before $29 \mathrm{dpp}$, and changes in body weight of females and lambs. Within the induction protocol, the onset of estrus, parity, fecundity and prolificacy were evaluated. The number of females that resumed their ovarian activity before $29 \mathrm{dpp}$ was determined by the number of females that ovulated (detected by the amount of serum $\mathrm{P}_{4}$ ), weight change in females and lambs determined from weight data obtained every $9 \mathrm{~d}$ until $81 \mathrm{dpp}$, estrus onset was calculated as the estrus time of the females after removal of the $\mathrm{P}_{4}$ device, calving was calculated as the number of females that gave birth out of the total number of females in the treatment after the first service, fertility was calculated as the number of lambs born among the number of females in the treatment, and prolificacy was measured as the number of lambs born per female lamb.

The percentage of females that ovulated at $29 \mathrm{dpp}$ and the percentage of calving were analyzed using a logistic regression model. Body weight change in females and lambs was analyzed using repeated measures in the Mixed model (Littell et al., 1998), and significantly different means were compared with the Tukey test. Initiation of estrus was analyzed using the life-time method and significant differences among treatments were assessed using the Long-Rank test (Kalbfleish \& Prentice, 2002). The Poisson and Negative Binomial regressions (Lawless, 1987) were used to analyze fecundity and prolificity, respectively. To test for significant differences among treatments, a generalized likelihood ratio test was used with a significance level of $\alpha=0.05$. All analyzes were performed using SAS (2002) version 9 (SAS Institute Inc., Cary, North Carolina, USA). 


\section{Results}

Exposure of the females to the male in T4 and without the administration of a metabolic restorative (T3) increased the percentage of ovulation at 29 days post-partum with respect to the females without exposure $(P \leq 0.05 ; \mathrm{T} 1$ and T2; Table 1$)$.

Table 1 Reproductive variables for Pelibuey females subjected to a male effect for 25 days and a metabolic restorative (Metabolase ${ }^{\circledR}$ )

\begin{tabular}{lccccccc}
\hline $\mathbf{T}$ & $\mathbf{n}$ & $\begin{array}{c}\text { Ovulation } \\
(\%)\end{array}$ & $\begin{array}{c}\text { Inseminated } \\
\text { females }\end{array}$ & $\begin{array}{c}\text { Estrus initiation } \\
(\mathbf{h})\end{array}$ & $\begin{array}{c}\text { Calving } \\
(\%)\end{array}$ & $\begin{array}{c}\text { Fecundity } \\
\text { (Mean } \pm \text { SE) }\end{array}$ \\
\hline $\mathrm{T} 1$ & 29 & $44.8^{\mathrm{a}}$ & 29 & $25.9^{\mathrm{ab}} \pm 1.9$ & $55.2^{\mathrm{a}}$ & $1.0^{\mathrm{a}} \pm 0.2$ & $1.9^{\mathrm{a}} \pm 0.2$ \\
$\mathrm{~T} 2$ & 29 & $48.3^{\mathrm{a}}$ & 29 & $25.7^{\mathrm{a}} \pm 0.7$ & $86.2^{\mathrm{b}}$ & $1.8^{\mathrm{a}} \pm 0.2$ & $2.0^{\mathrm{a}} \pm 0.2$ \\
$\mathrm{~T} 3$ & 32 & $75.0^{\mathrm{b}}$ & 32 & $31.1^{\mathrm{c}} \pm 1.6$ & $62.5^{\mathrm{a}}$ & $1.4^{\mathrm{a}} \pm 0.2$ & $2.3^{\mathrm{a}} \pm 0.2$ \\
$\mathrm{~T} 4$ & 30 & $73.3^{\mathrm{b}}$ & 28 & $28.6^{\mathrm{bc}} \pm 1.7$ & $60.7^{\mathrm{a}}$ & $1.4^{\mathrm{a}} \pm 0.2$ & $2.4^{\mathrm{a}} \pm 0.2$ \\
\hline
\end{tabular}

T: Treatment

Values with different superscripts in each column are significantly different $(P \leq 0.05)$

T1: Continuous suckling (CS)

T2: CS + Metabolic restorative (MR); applied on day 36 post-partum

T3: CS + Male effect (ME)

T4: $C S+M R+M E$

Weight changes among females were similar among treatments, but varied $(P \leq 0.05)$ over time (Figure 2). Among lambs, changes in body weight were linear over time $(P \leq 0.05$; Figure 3$)$.

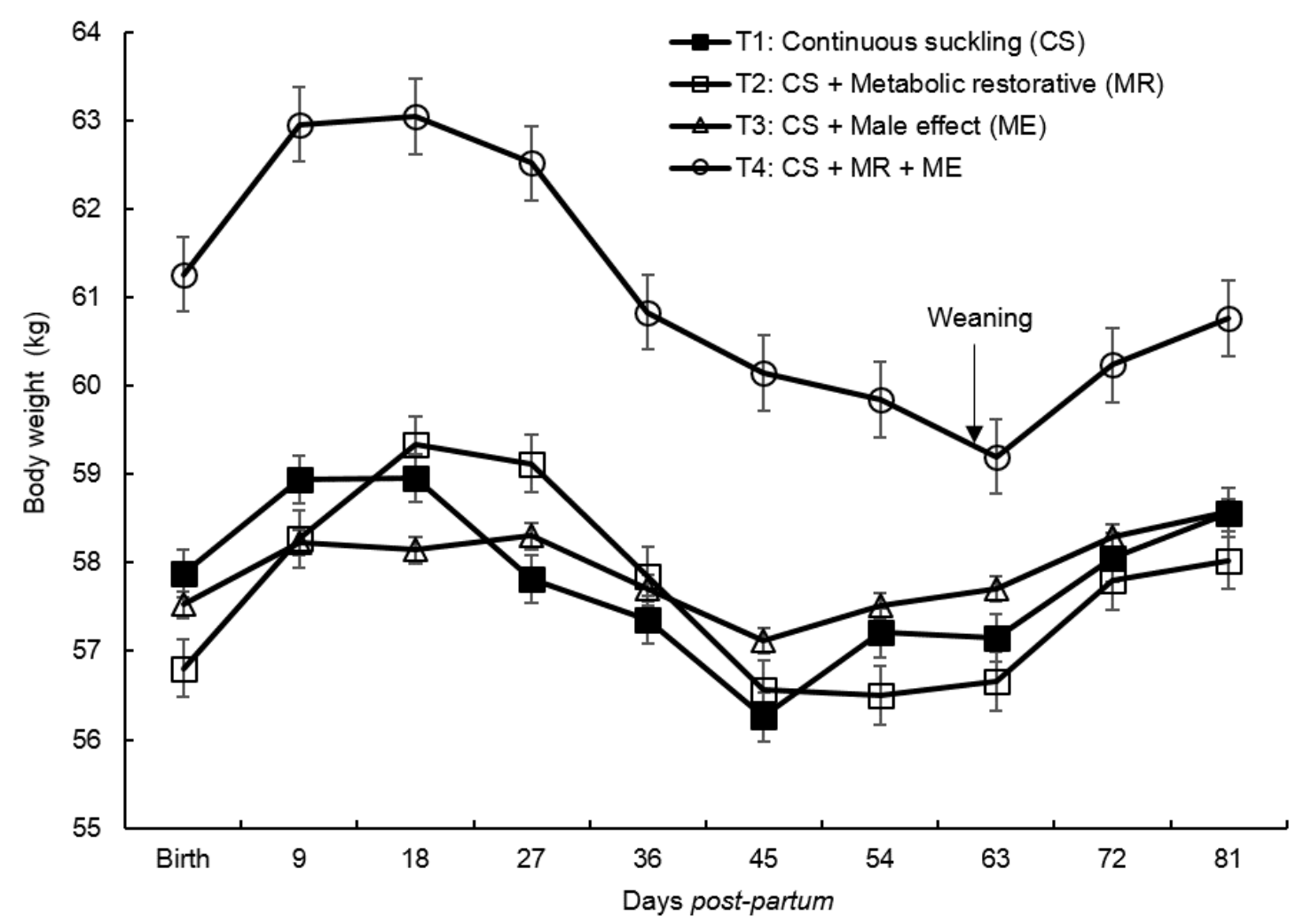

Figure 2 Body weight change among Pelibuey females during post-partum when subjected to a male effect for 25 days and a metabolic restorative (Metabolase $\AA$ ) 


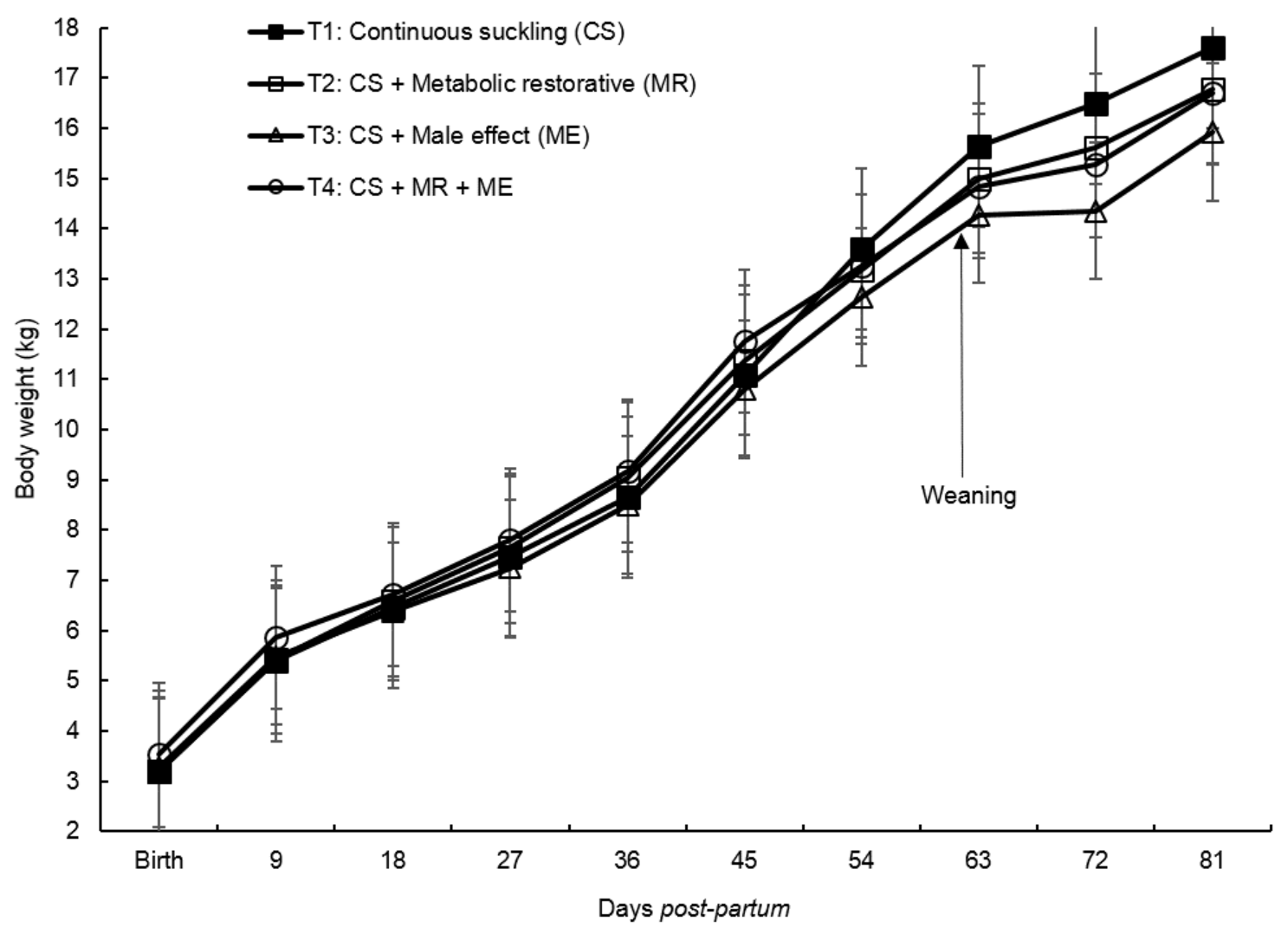

Figure 3 Body weight change among Pelibuey lambs over the first 81 days of age

Initiation of estrus differed $(P \leq 0.05)$ among females with the application of the metabolic restorative (T2) with respect to females exposed to the male effect (T3) and its combination (T4), but was similar to the control (T1). Females receiving a male effect (T3) had the most time to initiate estrus (Table 1). The highest percentage of lambing was with females receiving the metabolic restorative (T2; $P \leq 0.05)$ compared to the other treatments (Table 1). There were no significant differences among treatments $(P>0.05$; Table 1$)$ for fecundity and prolificacy.

\section{Discussion}

In females ovulating at 29 days post-partum, treatment responses were due to male stimulatory effects, since each reintroduction of a ram to the females induced an increase in the pulses of GnRH and LH as reported by Hawken et al. (2008). These successive increases led to ovarian reactivation in females and their ovulation (Bedos et al., 2010). In a similar study, Morales-Terán et al. (2011) introduced males for two 30 -min time periods and observed $65 \%$ of females ovulating at 50 days post-partum, a longer time than that obtained in the present study, suggesting the difference is due to the amount of contact time between males and females. Lassoued et al. (2004) found that all females ovulated with the continuous presence of a male before 50 days post-partum, with the mean number of days at first ovulation being $20.3( \pm 9.7)$. These results suggest that the introduction of males is a positive stimulus for reactivating the cycling of females in postnatal anestrus, reducing the negative effects of estradiol and suckling, and increasing the probability of a more rapid pregnancy when they reinitiate their sexual activity, thus reducing the post-partum period.

During the first two post-partum periods, weight gain was observed in all females due to their good body condition at the time of delivery, and their adequate alimentation which satisfied their nutritional requirements by preventing females from losing nutrients and body weight. Pérez-Hernández et al. (2009) and Morales-Terán et al. (2011) mention that females spending all day with their lambs tend to lose more weight than those who have controlled suckling, due to a greater synthesis of milk at the expense of their body reserves. Godfrey \& Dodson (2003) mention that weight loss during lactation limits the reestablishment of cycling in females, which is why poor body condition prolongs the post-partum interval. Castillo-Maldonado 
et al. (2013) report that in females whose nutritional requirements were covered, there were no significant differences between body weights in continuous and controlled suckling groups.

In the present study, weight loss was observed among females during days 27 to 45 (Figure 2). Lambs need more nutrients for growth during this period, such that females must use more nutrients for milk production, which is reflected as higher weights in lambs (Figure 3). Relling and Mattioli (2002) suggest that during weeks three to eight, lambs need more nutrients because milk does not meet their needs, and it is necessary to provide them with solid food. After $45 \mathrm{~d}$ the females gained weight until weaning, where they again lost weight due to separation from the young, and then gained weight once again (Figure 2).

In our study lamb weight always increased, yielding an average weaning weight of $15 \mathrm{~kg}$, which was acceptable compared to values reported by other authors for hair lambs (11-17 kg. Pérez-Hernández et al., 2009; Morales-Terán et al., 2011; Hinojosa-Cuéllar et al., 2012). Differences in mother pre- and post-partum feeding, as well as the quantity and quality of lamb feed supplements, partially explain lamb weaning weight. After weaning, lamb body weight declined due to separation from their mothers, after which they gained weight (Figure 3).

Of the induction protocol, the responses observed to the application of the metabolic restorative during the experiment was due to the improved metabolic state of the sheep, triggering positive effects on follicle development and estrogen production, and a more rapid and homogenous onset of estrus. However, application of the metabolic restorative improved this response in females which also received a male effect (T4). In post-partum females, Castillo-Maldonado et al. (2013) found that estrus began at 60 and $72 \mathrm{~h}$ after CIDR removal for treatments $C S$ and $C S+M E$, respectively, both of which were higher than results from the present study. Such results suggest that management of rams shortens the onset of estrus compared to other protocols during post-partum and that the application of the metabolic restorative accelerates the onset of estrus, and reduces the variation of its onset among females.

Nutrient provision to females favors ovum production, and their fertilization and implantation, thus improving fertility and prolificacy, and increasing embryo survival (Rivas et al., 2011). This likely occurred in females receiving the metabolic restorative, which helped improve follicle development, the quality of corpora lutea and embryo survival to maintain gestation and achieve successful birth. Exposure of females to males resulted in shorter estrus cycles, generally observed after the first post-partum ovulation (Flores et al., 2000). The corpora lutea in this case, were of low quality and not capable of maintaining gestation, and thus were absorbed. The lowest percentages of calving were obtained in females with continuous suckling (T1; Table 1 ), tending to decrease, confirming that suckling is a factor strongly influencing the inhibition of ovarian activity.

No differences were found for fecundity and prolificacy, although values were higher than those reported by Castillo-Maldonado et al. (2013) who report a fecundity of 1.5 and a prolificacy of 1.7 for hair sheep using continuous suckling, progestins and a male effect.

\section{Conclusion}

We conclude that a male effect positively influenced the reestablishment of ovarian activity, with the onset of cyclic activity among females before 29 days post-partum, thus shortening this period. Therefore, compared with other studies reported, the metabolic restorative could improve the fertility of hair ewes even in continuous suckling with similar hormone protocol.

\section{Acknowledgements}

The authors thank the Campus Montecillo of Colegio de Postgraduados and the Reproduction Labortory for Sheep and Goats (LaROCa) for their financial support.

\section{Authors' Contributions}

SFC carried out the research work and wrote the manuscript, based on the PhD thesis de SFC, under the supervision of JGO, JSO, CCR, PPH and CAHR. Data were collected by SFC, and analysis of data and interpretation of results was led by JGS with the assistance of PPH, JSO, CCR and CAHR. Critical revisión and final approval of the versión to be published were done by JGS, PPH and SFC.

\section{Conflict of Interest Declaration}

The authors certify that they have no affiliations with any organisation or entity with any financial or non-financial interest in the subject matter or materials discussed in this manuscript.

\section{References}

Álvarez, R.L., \& Zarco, Q.L.A., 2001. Los fenómenos de bioestimulación sexual en ovejas y cabras. Vet. Méx. 32, 117129. 
Arroyo-Ledezma, J., Pérez-Hernández, P., Porras-Almeraya, A.I., Vaquera-Huerta, H., Pro-Martínez, A. \& GallegosSánchez, J., 2000. Amamantamiento y concentración sérica de progesterona (P4) posparto en ovejas Pelibuey. Rev. Chapingo. 3, 47-54.

Bedos, M., Flores, J.A., Fitz-Rodríguez, G., Keller, M., Malpaux, B., Poindron, P. \& Delgadillo, J.A., 2010. Four hours of daily contact with sexually active males is sufficient to induce fertile ovulation in anestrous goats. Horm. Behav. 58, 473-477.

Castillo-Maldonado, P.P., Vaquera-Huerta, H., Tarango-Arámbula, L.A., Pérez-Hernández, P., Herrera-Corredor, C.A. \& Gallegos-Sánchez, J., 2013. Restablecimiento de la actividad reproductiva posparto en ovejas de pelo. Arch. Zootec. 62, 419-428.

Durmic, Z., \& Blache, D., 2012. Bioactive plants and plant products: effects on animal function, health and welfare. Anim. Feed Sci. Technol. 176, 150-62.

Flores, J.A., Véliz, F.G., Pérez-Villanueva, J.A., Martínez-Escalera, G., Chemineau, P., Poindron, P., Malpaux, B. \& Delgadillo, J.A., 2000. Male reproductive condition is the limiting factor of efficiency in the male effect during seasonal anestrus in female goats. Biol. Reprod. 62, 1409-1414.

García, E., 2004. Modificaciones al sistema de clasificación climática de Köppen, para adaptarlo a las condiciones de la República Mexicana (5 th ed.). Instituto de Geografía, UNAM. México. 90 pp.

Godfrey, R.W., \& Dodson, R.E., 2003. Effect of supplemental nutrition around lambing on hair sheer ewes and lambs during the dry and wet seasons in the U.S. Virgin Islands. J. Anim. Sci. 81, 587-593.

Hawken, P.A., Evans, A.C. \& Beard, A.P., 2008. Prior exposure of maiden ewes to rams enhances their behavioural interactions with rams but is not a pre-requisite to their endocrine response to the ram effect. Anim. Reproduc. Sci. 108, 13-21.

Hinojosa-Cuéllar, J.A., Oliva-Hernández, J., Torres-Hernández, G., Segura-Correa, J.C., Aranda-lbáñez, E.M. \& González-Camacho, J.M., 2012. Factores que afectan el crecimiento pre-destete de corderos Pelibuey en el trópico húmedo de México. Universidad y Ciencia. 28, 163-171.

Kalbfleisch, D.J., \& Prentice, R.L., 2002. The Statistical Analysis of Failure Time Data (2th ed.). Wiley-Interscience / John Wiley \& Sons. Inc., Publication. New Jersey, United States of America. 462 pp.

Lassoued, N., Naouali, M., Khaldi, G. \& Rekik, M., 2004. Influence of the permanent presence of rams on the resumption of sexual activity in postpartum Barbarine ewes. Small. Rumin. Res. 54, 25-31.

Lawless, F.J., 1987. Negative binomial and mixed Poisson regression. Can. J. Stat. 15, 209-225.

Littell, R.C., Henry, P.R. \& Ammeman, C.B., 1998. Statistical analysis of repeated measures data using SAS procedures. J. Anim. Sci. 76, 1216-1231.

Martin, G.B., \& Reza, F.T., 2016. Clean, Green, ethical (CGE) Management: What Research Do We Really Need?. Int. J. Trop. Vet. Biomed. Res. 1(1), 1-9.

Morales-Terán, G., Herrera-Corredor, C.A., Pérez-Hernández, P., Salazar-Ortiz, J. \& Gallegos-Sánchez, J., 2011. Influence of controlled suckling and the male effect on the resumption of postpartum ovarian activity in Pelibuey sheep. Trop. Subtrop. Agroecosys.13, 493-500.

Pérez-Hernández, P., Hernández, V.V.M., Figueroa, S.B., Torres, H.G., Díaz, R.P. \& Gallegos-Sánchez, J., 2009. Efecto del tipo de amamantamiento en la actividad ovárica postparto de ovejas Pelibuey y tasas de crecimiento de corderos en los primeros 90 días de edad. Rev. Cient. FCV-LUZ. 19, 343-349.

Relling, A.E., \& Mattioli, G.A., 2002. Fisiología Digestiva y Metabólica de los Rumiantes (2th ed.). Universidad Nacional de La Plata-EDULP, Argentina. $72 \mathrm{pp}$.

Rivas, L.P.C., Suárez, L.A. \& Ramírez, C.E., 2011. Influencia de las hormonas metabólicas y la nutrición en el desarrollo folicular en el ganado bovino: implicaciones prácticas. Rev. Med. Vet. 21, 155-173.

SAGARPA. Diario Oficial de la Federación. Norma Oficial Mexicana 024 y 033-ZOO-1995. Access date June 2015. URL: http://sagarpa.gob.mx/normateca/normateca2/SENASICA\%20NORM\%2028.pdf $\quad$ and http://dof.gob.mx/nota detalle.php?codigo=4883147\&fecha=16/10/1995

SAS (Statistical Analysis System), 2002. SAS/STAT $® 9.0$ User's Guide (Business Analytics software). SAS Institute, Inc., Cary, North Carolina, USA.

Ungerfeld, R., \& Sánchez-Dávila, F., 2012. Oestrus synchronization in postpartum autumn-lambing ewes: effect of postpartum time, parity, and early weaning. Spanish J. Agr. Res. 10(1), 62-68.

Viana, N.A.M., Flores, S.M.G., Pinto, A.E., Salles, R.I.C., Ramos, R.D. \& Alencar, A.A., 2016. Male effect: Sustainability and effectiveness in inducing estrus in goats. J. Vet. Androl. 1(1), 13-23. 